\title{
Multi-Scale, Multi-Season, Multi-Indicator Evaluation of Agricultural Drought Trends in Ethiopia -Implications to Dryland Agriculture and Food Security
}

Dawd Temam $^{1}$, V. Uddameri ${ }^{1,2, *}$, G. Mohammadi ${ }^{2}$, E. A. Hernandez ${ }^{2}$, S. Ekwaro-Osire ${ }^{3,4}$

Abstract:

${ }^{1}$ Department of Civil Engineering, Jimma Institute of Technology, University of Jimma, Jimma Ethiopia

${ }^{2}$ Department of Civil, Environmental and Construction Engineering, Texas Tech University, Lubbock, TX 79409, USA

${ }^{3}$ Department of Mechanical Engineering, Jimma Institute of Technology, University of Jimma, Jimma Ethiopia

${ }^{4}$ Department of Mechanical Engineering, Texas Tech University, Lubbock, TX 79409, USA

*Corresponding Author (email: venki.uddameri@ttu.edu; Ph: 806-834-8340)

\section{Abstract:}

Ethiopian agriculture is not only affected by precipitation declines (meteorological droughts) but also soil dryness caused by temperature increases and associated long-term hydrological changes. Meteorological drought indicators (e.g., SPI), do not fully capture the water deficits in agricultural systems (i.e., agricultural droughts). An Ethiopia-wide assessment of meteorological and agricultural drought trends was carried out to characterize century-scale $(1902-2016)$ changes in droughts. SPI and SPEI calculated using two-month accumulation and the Palmer Z-index were used for assessing intra-season drought trends. SPI and SPEI at six-month accumulations and PDSI were used to define full season droughts. Detrended variance corrected Mann-Kendall test was used for trend analysis during Bega (dry), Belg (short-rainy) and Meher (long-rainy) seasons. The SPEI-2 and PDSI were most aggressive in characterizing intra-season and seasonal-drought trends. There is on average 1\%-6\% annual increase in dryness with the lower estimate based on precipitation declines and the upper end accounting for seasonal soil moisture dynamics. The area between $37.5^{\circ} \mathrm{E}-42.5^{\circ} \mathrm{E}$ denotes a climate hot-spot. Precipitation declines in Belg along the Ethiopia-South-Sudan/Sudan border during Belg and along Eretria-Ethiopia border during Meher have the potential to exacerbate transboundary water conflicts and further threaten the food security of the region.

Keywords: SPI, SPEI, PDSI, Palmer Z-index, Ethiopia, Food Security, Climate Change, droughts, Trend Analysis, Autocorrelation, droughts 
1

2 Ethiopia is predominantly rural with a large population dependent on agriculture and pastoral

3 activities but there has been limited development of surface and groundwater resources (blue

4 water) for irrigation [1]. Dryland farming is widely practiced in Ethiopia and accounts for over

5 two-thirds of all agricultural land [2]. The nexus between rainfall and agriculture is so strong in

6 Ethiopia that that the words drought and famine are often used interchangeably in the media [3].

7 Food security in rural Ethiopia is intimately tied to precipitation patterns. Droughts have

8 frequently plagued Ethiopia and continue to be perceived as a major climate change threat affecting

9 the long-term viability of rural livelihoods in the country [4,5].

10

11 Ethiopia is characterized by a high spatiotemporal rainfall variability [6] with as many as 14

12 different precipitation zones [7]. Precipitation exhibits a strong elevation dependency and is much

13 greater in the highlands than lowlands, except perhaps in the west. Annual precipitation

14 accumulations across the nation range from under $400 \mathrm{~mm}$ to over $2000 \mathrm{~mm}$ [8]. On an intra-

15 annual basis, rainfall in Ethiopia exhibits a trimodal behavior. The main rainy season, (June -

16 September) also known as Kiremt exists over all of Ethiopia except perhaps in southern and

17 southeastern parts. The agricultural season corresponding with this rainfall is referred to as Meher.

18 Both Meher and Kiremt are used interchangeably in local parlance and this practice will be adopted

19 here as well. The country is generally dry during the months of October - January, except for the

20 central part which receives some rainfall. This relatively dry period is locally referred to as Bega.

21 The Belg is the shorter rainy season that extends from February - May but is the primary source

22 of water in the southern and southeastern part of the nation [9]. 
1 The major crops in Ethiopia include a variety of grains (cereals), oilseeds and coffee [10]. Single

2 season crops (wheat, teff and barley) are harvested during both Belg (5\% - 10\% of total production)

3 and Meher (45\% - 50\% of total production). Long-cycle crops, (e.g., sorghum and maize) are

4 grown over both the seasons (Belg and Meher) and account for nearly 50\% of the total crop

5 production [11]. The period between April - September/October represents the growing phase of

6 the long-season crops. Pastoralists account for about 15\% of the nation's population and depend

7 on rainfall for healthy grasslands and water for their livestock throughout the year [12].

9 Understanding drought characteristics is essential for agricultural and livestock adaptations to

10 climate change as well as sustainable water resources management in Ethiopia [5,13]. Several

11 studies have been undertaken in recent years to evaluate precipitation trends and drought

12 characteristics in various regions of Ethiopia [14,15]. The results from these trend analysis studies

13 (summarized in Table 1) indicate several characteristics - 1) Most studies focus on a specific

14 region and often employ datasets with less than 30 years of records, even national-scale studies

15 are limited in the number of stations that are used due to long periods of missing records; 2) There

16 is often significant intra-station variability even within a region (watershed) with some stations

17 indicating trends while others showing no trends; 3) Mann-Kendall test typically without

18 corrections for autocorrelation or linear regression are used to assess trends; 4) drought studies

19 are predominantly focused on the standardized precipitation index (SPI) or meteorological

20 droughts with a greater emphasis placed on higher accumulation periods (e.g., 12 months); 5)

21 Declining precipitation trends are more consistently noted in south and southwestern portions of

22 the country than in other parts of the nation. 
Table 1: Major Hydroclimatic Trend Analysis Studies in Ethiopia

\begin{tabular}{|c|c|c|c|c|c|}
\hline Study & Indicator & Region & Period & Findings & Approach \\
\hline [9] & Rainfall & $\begin{array}{l}11 \text { Key Stations } \\
\text { across Ethiopia }\end{array}$ & $1965-2002$ & $\begin{array}{l}\text { Annual and Kiremt rainfall } \\
\text { declines in Eastern, Southern } \\
\text { and Southwestern Ethiopia }\end{array}$ & $\begin{array}{c}\text { Original } \\
\text { Mann Kendall } \\
\text { Test }\end{array}$ \\
\hline [16] & $\begin{array}{l}\text { Rainfall } \\
\text { extremes }\end{array}$ & $\begin{array}{l}11 \text { Key Stations } \\
\text { across Ethiopia }\end{array}$ & $1965-2002$ & $\begin{array}{l}\text { Extreme Seasonal Rainfall of } \\
\text { Belg and Kiremt declined in } \\
\text { Eastern, Southern and } \\
\text { Southwestern Parts }\end{array}$ & $\begin{array}{c}\text { Original } \\
\text { Mann Kendall } \\
\text { Test }\end{array}$ \\
\hline [17] & $\begin{array}{c}\text { Rainfall; } \\
\text { Standardized } \\
\text { Rainfall } \\
\text { Anomaly }\end{array}$ & $\begin{array}{c}\text { Amhara Region } \\
\text { (12 stations) }\end{array}$ & $\begin{array}{c}\text { Longest } \\
\text { Period } \\
1961-2003 \\
\text { but varies } \\
\text { across stations }\end{array}$ & $\begin{array}{l}\text { No Consistent pattern or } \\
\text { trends in daily rainfall. Both } \\
\text { increasing and decreasing } \\
\text { trends were noted in the } \\
\text { region }\end{array}$ & $\begin{array}{l}\text { Correlograms; } \\
\text { Regression and } \\
\text { Sperman Rho } \\
\text { (correlation } \\
\text { coefficient) }\end{array}$ \\
\hline [18] & Rainfall & $\begin{array}{l}13 \text { Watersheds } \\
\text { and } \\
124 \text { stations }\end{array}$ & $1960-2002$ & $\begin{array}{l}\text { Kiremet rainfall declines at a } \\
\text { few gaging stations in Baro- } \\
\text { Akobo, Omo-Ghibe, Rift } \\
\text { Valley, and Southern Blue } \\
\text { Nile Watersheds. } \\
\text { However, no regional or } \\
\text { watershed scale trends }\end{array}$ & $\begin{array}{l}\text { Regression } \\
\text { against time }\end{array}$ \\
\hline [15] & SPI & $\begin{array}{c}\text { Awash River } \\
\text { Basin }\end{array}$ & $\begin{array}{l}30 \text { stations } \\
\text { with a } \\
\text { maximum } \\
\text { period of } \\
\text { record of } \\
1963-2003\end{array}$ & $\begin{array}{l}\text { SPI2 correlates well with } \\
\text { streamflow (hydrologic } \\
\text { droughts); } \\
\text { Middle and Lower Awash } \\
\text { Basin is more prone to } \\
\text { droughts with comparison on } \\
\text { SPI } 12\end{array}$ & $\begin{array}{l}\text { Theory of runs } \\
\text { and } \\
\text { GIS mapping }\end{array}$ \\
\hline [19] & $\begin{array}{l}\text { Rainfall, } \\
\text { Landcover } \\
\quad \text { and } \\
\text { Streamflow }\end{array}$ & $\begin{array}{l}9 \text { Weather } \\
\text { Stations } \\
\text { Upper Gilgil } \\
\text { Abbey - Blue } \\
\text { Nile Basin }\end{array}$ & 1973- 2005 & $\begin{array}{l}\text { Statistically decreasing trend } \\
\text { in rainfall for most months but } \\
\text { increasing trends during most } \\
\text { of Kiremt } \\
\text { (June, July August) }\end{array}$ & $\begin{array}{c}\text { Monthly } \\
\text { Mann Kendall } \\
\text { Test }\end{array}$ \\
\hline
\end{tabular}




\begin{tabular}{|c|c|c|c|c|c|}
\hline Study & Indicator & Region & Period & Findings & Approach \\
\hline [20] & $\begin{array}{l}\text { Rainfall, } \\
\text { Temperature }\end{array}$ & $\begin{array}{c}\text { Ethiopia; } \\
\text { Gaging stations }\end{array}$ & $\begin{array}{l}\text { Mid 1970s - } \\
\text { late 2000s }\end{array}$ & $\begin{array}{l}\text { Belg and Kiremt rainfall has } \\
\text { declined in parts of southern, } \\
\text { south central, southwestern } \\
\text { and southeastern Ethiopia. } \\
\text { Temperature has increased } \\
\text { over this time period }\end{array}$ & $\begin{array}{l}\text { Kriging, } \\
\text { Spatial Mapping } \\
\text { and Trend } \\
\text { analysis }\end{array}$ \\
\hline [21] & $\begin{array}{l}\text { SPI } 3,46,9, \\
12,24 \text { months }\end{array}$ & $\begin{array}{l}\text { Ethiopia; GPCC } \\
\text { gridded data } \\
\left(2.5^{\circ} \times 2.5^{\circ}\right) \\
\text { ERA reanalysis } \\
\text { products as well } \\
\text { as } 238 \text { Gage } \\
\text { Stations }\end{array}$ & 1970- 2011 & $\begin{array}{l}\text { Precipitation Decline in } \\
\text { Southern Ethiopia for both } \\
\text { Belg and Kiremt; No trends in } \\
\text { Central and Northern Parts }\end{array}$ & $\begin{array}{l}\text { Regression } \\
\text { against time; } \\
\text { Bootstrap } \\
\text { confidence } \\
\text { Intervals }\end{array}$ \\
\hline [22] & $\begin{array}{l}\text { PDSI and } \\
\text { PDSI-sc }\end{array}$ & $\begin{array}{l}\text { Northern and } \\
\text { Northwest parts } \\
\text { of Ethiopia }\end{array}$ & $\begin{array}{l}\text { 1901-2014; } \\
\text { CRU Data } \\
(0.5 \times 0.5 \\
\text { grid })\end{array}$ & $\begin{array}{l}\text { Increase in temperature and } \\
\text { characterization of drought } \\
\text { frequencies }\end{array}$ & $\begin{array}{l}\text { GIS Mapping } \\
\text { and } \\
\text { Visualization }\end{array}$ \\
\hline [23] & Rainfall & $\begin{array}{l}12 \text { Stations in } \\
\text { Awash River } \\
\text { Basin }\end{array}$ & $\begin{array}{l}\text { Variable. } \\
\text { Maximum } \\
\text { Period of } \\
\text { Record } \\
1980-2012\end{array}$ & $\begin{array}{l}\text { No significant change in Belg } \\
\text { but a decline in Kiremt } \\
\text { Rainfall }\end{array}$ & $\begin{array}{l}\text { Mann-Kendall } \\
\text { and Sen Slope }\end{array}$ \\
\hline [24] & $\begin{array}{l}\text { Rainfall, } \\
\text { Temperature } \\
\text { and } \\
\text { Agricultural } \\
\text { Production }\end{array}$ & $\begin{array}{c}18 \text { stations } \\
\text { across Ethiopia }\end{array}$ & $\begin{array}{l}\text { Variable } \\
\text { Maximum } \\
\text { Period of } \\
\text { Record } \\
\text { 1952-2015 }\end{array}$ & $\begin{array}{l}\text { No discerning trends overall } \\
\text { in precipitation; Annual } \\
\text { temperature has risen over the } \\
\text { period }\end{array}$ & $\begin{array}{c}\text { Exploratory } \\
\text { analysis using } \\
\text { charts and tables }\end{array}$ \\
\hline [25] & $\begin{array}{l}\text { Rainfall and } \\
\text { Temperature; } \\
\text { SPI and } \\
\text { STARDEX } \\
\text { Indices }\end{array}$ & $\begin{array}{l}\quad 87-120 \\
\text { weather stations } \\
\text { across Ethiopia }\end{array}$ & 1982-2012 & $\begin{array}{l}\text { No significant change in } \\
\text { annual or bimodal } \\
\text { (Belg and Kiremt rainfall); } \\
\text { Increase in temperatures; } \\
\text { Increase in rainfall intensity in } \\
\text { most stations }\end{array}$ & $\begin{array}{l}\text { Regression } \\
\text { against time and } \\
\text { GIS mapping }\end{array}$ \\
\hline [26] & $\begin{array}{l}\text { Rainfall and } \\
\text { Temperature; } \\
\text { PDSI }\end{array}$ & $\begin{array}{l}\text { North Central } \\
\text { Ethiopia } \\
\text { (Woleka } \\
\text { Sub-basin) }\end{array}$ & 1901-2014 & $\begin{array}{l}\text { Annual, Kiremt and Belg } \\
\text { rainfall has declined. Annual } \\
\text { and Kiremt rainfall declines } \\
\text { are statistically significant }\end{array}$ & $\begin{array}{l}\text { Mann-Kendall } \\
\text { with } \\
\text { Autocorrelation }\end{array}$ \\
\hline
\end{tabular}


1 Trend studies are often noted to be contradictory or inconclusive and are known to depend upon

2 regional divisions and the amount of quality data that are used to estimate trends [18,27]. In

3 addition, the use of linear regression or traditional Mann-Kendall tests may not be appropriate in

4 some instances due to the presence of autocorrelation in these datasets.

6 Meteorological droughts focus on the atmospheric moisture deficits and delineating their trends is

7 undoubtedly important in Ethiopia given its high reliance on rainfed agricultural practices.

8 However, the onset of an agricultural drought is typically marked by deficiencies in soil moisture

9 [28] which is a complex function of precipitation as well as soil and land use characteristics of the

10 watershed. The onset and cessation of agricultural droughts need not coincide with those of

11 meteorological droughts. Antecedent soil moisture can help buffer the soil initially to withstand

12 meteorological droughts. In a similar vein, soil dryness may continue to occur even after the

13 cessation of meteorological droughts because of deep percolation and evapotranspiration.

14 Therefore, trends in meteorological droughts may not translate to trends in agricultural droughts

15 or vice-versa.

16

17 While soil moisture is regarded as the master variable to define agricultural droughts, the

18 challenges in obtaining reliable soil moisture measurements greatly limits its use in drought

19 studies. As plant water uptake is a function of temperature-controlled evapotranspiration, drought

20 indicators that incorporate potential evapotranspiration (PET) are often used to characterize

21 agricultural droughts [29]. In particular, the self-calibrating Palmer Drought Severity Index

22 (PDSIsc) proposed by Wells et al. [30], and the associated Z-index [31] as well as the Standardized

23 Precipitation Evapotranspiration index (SPEI) proposed by Vicente-Serrano et al. [32], have been 
1 successfully used to characterize agricultural droughts in many parts of the world [33-35]. These

2 indicators have however seen limited use in the Ethiopian context [22].

4 SPI, SPEI and PDSIsc are based on different physical aspects - SPI strictly focuses on precipitation

5 which is controlled by global moisture movements and climate teleconnections; SPEI is based on

6 a simple atmospheric water budget and PDSI (and therefore the Z-index) uses a two-bucket model

7 for representing soil water budgets. As these drought indicators are based on different physical

8 aspects and all have their own strengths and weaknesses, their ability to capture different drought

9 characteristics may be different. It is therefore becoming a common practice to evaluate droughts

10 using multiple indicators [36-38].

12 A simultaneous assessment of drought trends using multiple drought indicators is useful for

13 drought planning and management studies. While some indicators may detect droughts in one

14 season (say dry) another might exhibit greater sensitivity in a different (say wet) season. If various

15 drought indicators (which are computed using different parameters and conceptualizations) all

16 exhibit similar trends, then there will be greater confidence in the detected trend as all available

17 information is pointing to the change. In such an instance, the use of a simpler drought index (e.g.,

18 one based on precipitation alone) would be validated and deemed reasonable for trend detection.

19 If different drought indices exhibit diverging trends, then additional insights with regards to the

20 underlying mechanisms driving droughts can be ascertained [39]. For example, if SPI exhibits no

21 trend but SPEI indicates an increasing drought trend then drying of soil moisture due to increased

22 temperatures (as opposed to precipitation deficits) is likely the dominant mechanism controlling 
1 agricultural droughts. Identification of such underlying factors are helpful to guide future data

2 collection activities and identify mechanistic shifts in drought producing processes [40].

4 The primary goal of the present study is to undertake a multi-indicator evaluation of agricultural 5 drought trends in Ethiopia. The study evaluates trends of drought severity for Bega, Belg and

6 Meher (Kiremt) seasons using four major drought indicators namely - SPI, SPEI and PDSIsc

7 (referred to as PDSI from here on for brevity) and Palmer Z-index (referred to as Z-index hereon).

8 A simultaneous comparison of drought trends from multiple indicators is an important knowledge

9 gap in Ethiopian context that this study seeks to address. In addition, the study also aims to

10 overcome some other limitations identified in previous studies such as assessing trends using high

11 resolution spatio-temporal datasets and choosing techniques that appropriately deal with the nature

12 and extent of autocorrelation present in hydrometeorological datasets.

14 Datasets and Methods

15 Following Asfaw et al. [26], GPCC Full Data Monthly Product Version 2018 from Global

16 Precipitation and Climatology Center (GPCC) available on $0.5^{\circ} \times 0.5^{\circ}$ grid [41] were used along

17 with temperature data from Climate Research Unit (CRU TS 4.21) as described in Harris et al.

18 [42]. GPCC Full Data Monthly Product is the most comprehensive gridded precipitation dataset

19 available today and is based on measurements from over 80,000 stations worldwide. When this

20 study was conducted, the dataset covered a period ranging from January 1891 - December 2016

$21[38,43]$. While GPCC data are available at different spatial resolutions, the data with $0.5^{\circ} \times 0.5^{\circ}$

22 spatial resolution was used to be consistent with the resolution of the available temperature data. 
1 The precipitation data at the adopted resolution is known to provide reasonable estimates in

2 Ethiopia [26].

3

4 The CRU Climate Dataset is produced by the Climate Research Unit at the University of East

5 Anglia and is also gridded at a resolution of $0.5^{\circ} \times 0.5^{\circ}$ over the land mass and during the time of

6 this study, data were available at a monthly time-step from 1901-2017. The CRU dataset is again

7 based on long-term observations from several thousand stations worldwide that are compiled under

8 the auspices of World Meteorological Organization (WMO) and the National Oceanic and

9 Atmospheric Administration (NOAA through its National Climate Data Center, NCDC). This

10 dataset has also been used in several hundred climate change assessment studies and known to

11 provide reasonable estimates for temperature [42].

12

13 The adopted spatial resolution $\left(0.5^{\circ} \times 0.5^{\circ}\right)$ resulted in 377 locations wherein the nearest neighbors

14 are approximately $50 \mathrm{~km}$ apart (see Figure 1a). The 15 major water basins in Ethiopia are shown

15 in Figure $1 \mathrm{~b}$ and represent the federal level water planning boundaries of the nation. Figure 1c

16 shows the land use land cover (LULC) classification which highlights the rural nature of the

17 country with high reliance on climate-dependent agricultural and pastoral activities. As depicted

18 in Figure (1d), Ethiopia exhibits a great variation in relief ranging from areas below mean sea level

19 to mountain ranges that are over $4000 \mathrm{~m}$ high, Precipitation correlates strongly with elevation with

20 higher elevations getting more rainfall than lowlands. 


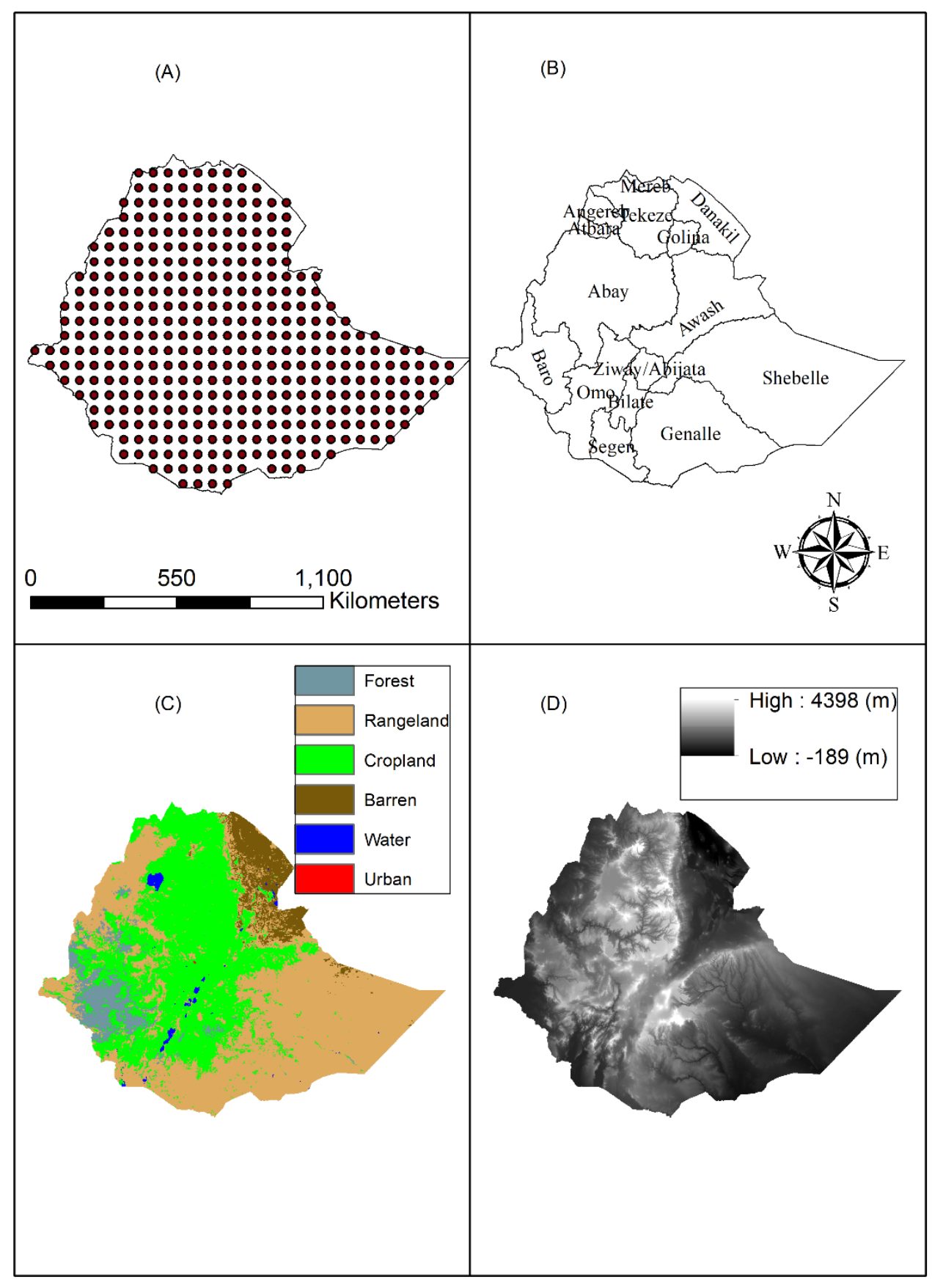

Figure 1: Study Grid and Geographical Characteristics of Ethiopa 
1 Four drought indicators - SPI, SPEI, PDSI and Z-Index were used to assess droughts. The SPI

2 and SPEI calculations were carried out using procedures presented in Stagge et al. [44], to correct

3 for zero precipitation values that are likely during dry months. As the study focuses on agricultural

4 droughts SPI and SPEI were computed at 2-, 3-, 4- and 6- month accumulations to evaluate both

5 intra-seasonal and full season trends. The analysis indicated that the results of intermediate

6 accumulation periods (3- and 4-months) yielded results that were similar to the bracketing

7 accumulation periods of 2- and 6-months. As such, the results are only presented here for 2-month

8 (intra-season) and 6-month (full-season) accumulations in the interest of brevity. The Z-Index

9 represents short-term (monthly) soil moisture dynamics as it factors out the long-term effects

10 embedded within PDSI [31,45]. Studies have indicated that PDSI does a better job of predicting

11 longer-term droughts [32] and is seen to correlate well with SPI and SPEI values computed using

12 higher accumulation periods [46]. Therefore SPI-2, SPEI-2 and Z-Index are used to characterize

13 intra-season or short-term droughts while SPI-6, SPEI-6 and PDSI are used as indicators of full-

14 season or long-term droughts.

16 The drought indicators were all computed on a monthly basis and then aggregated to obtain values

17 for seasonal climate states. For a hydrologic year, the seasons were defined as Bega (October-

18 January); Belg (February - May) and Meher (June - September). Trend analysis was carried out

19 over hydrologic years 1902 - 2016 (Oct. 1901 - Sep. 2016) and to the best of the authors'

20 knowledge this represents the longest assessment period in Ethiopia that has been documented in

21 the literature. Century-scale trend assessment studies, such as the one conducted here, better

22 capture a higher degree of climate variability than what is observed at shorter timespans which in 
1 turn helps minimize artifacts associated with any short-term or cyclical effects present in the

2 climate signals.

3

4 Exploratory data analysis indicated the presence of autocorrelation even when drought indicators

5 were aggregated over the season to create an annual time-series. Furthermore, autocorrelation

6 structures that were observed varied across indicators and in space (see Figure 2 for an illustrative

7 example). In all cases, at least the lag-1 autocorrelation was significant. Autocorrelation effects

8 from higher-order lags were also significant and had to be corrected for at several locations. Many

9 approaches have been suggested in the literature to properly assess trends in autocorrelated time-

10 series [47-50]. The detrended variance correction approach of Yue and Wang [50] was adopted

11 here because it has lower false detections than rank-based variance corrections methods [48,50];

12 is known for its ability to deal with higher order dependencies [51] and has statistical power

13 comparable to more computationally intensive block bootstrap methods [52]. Custom scripts were

14 developed in R software [53] that made use of available libraries and packages for pre-processing

15 data [54] calculating drought indicators [55,56] and performing variance corrected Mann Kendall

16 tests [57]. 
Northwest

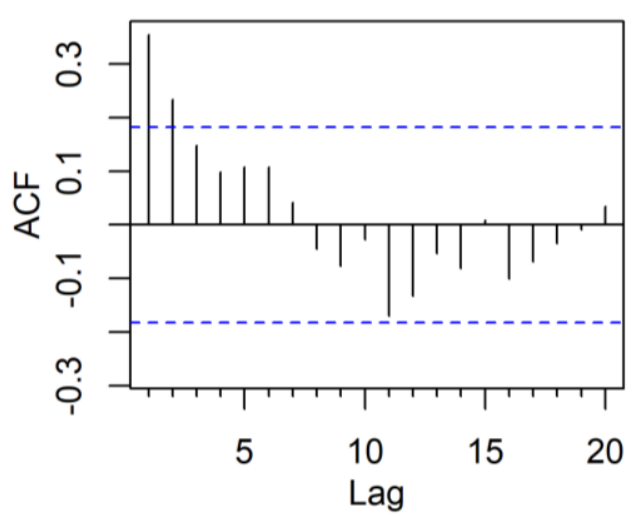

Southwest

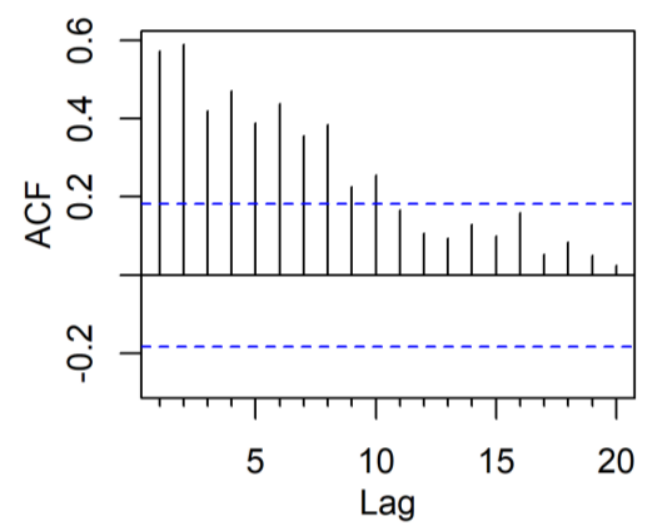

Northeast

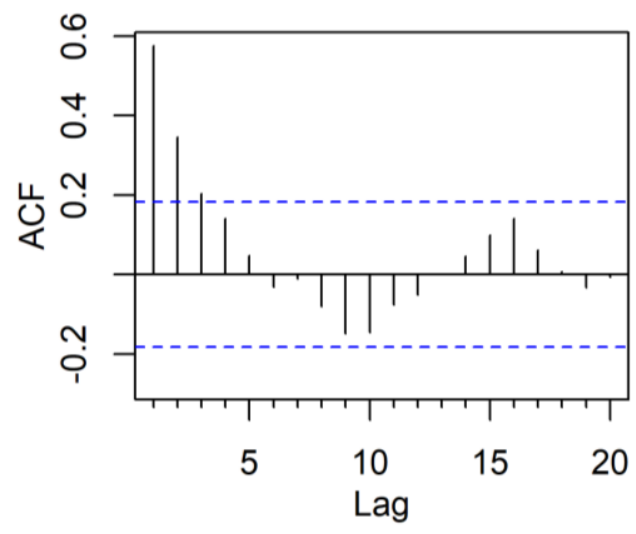

Southeast

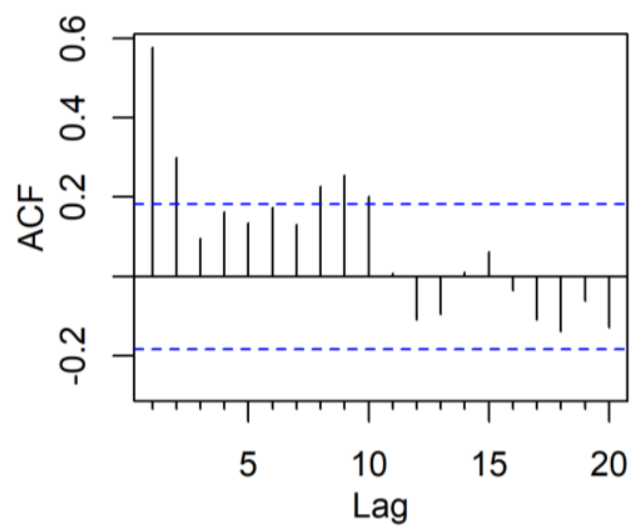

2 Figure 2: Illustrative Autocorrelation Functions Noted at Different Locations in Ethiopia for

PDSI

6 Indicators used in this study specify droughts with negative values (below a threshold) and wet

7 periods using positive values (above a threshold). As trend analysis was carried out using the

8 seasonally aggregated sum of the drought indicator, a negative trend implied the drought indicator

9 became more negative (or less positive) over time (i.e., increase in drought severity or a drying

10 trend) while a positive trend implied a shift towards more positive (or less negative) value over

11 time (decrease in drought severity or a wetting trend). 
2 Results and Discussion

3 Trends across Ethiopia during Bega Season:

4 The Bega season (October - January) has the lowest rainfall amounts compared to other seasons

5 within the year ( $\sim 2 \%$ of the annual precipitation of the country). Nonetheless, rainfall during

6 Bega is important for several reasons. Bega rains can be significant in the central portions of the

7 country. Bega rains provide much needed antecedent soil moisture that facilitates the tilling and

8 planting of Belg crops. Bega rains are also important to maintain grasses in rangelands that

9 pastoralists depend upon throughout the year. Therefore, declines in Bega rainfall can have

10 devastating impacts in both agricultural and pastoral activities of the nation.

12 Figure 3 depicts the century-scale drought trends during the Bega season across Ethiopia. The left

13 panel depicts short-term (intra-season) drought trends captured using SPI-2, SPEI-2 and Z-index

14 while the right panel depicts full season effects captured using SPI-6, SPEI-6 and PDSI. Declines

15 in precipitation (increased meteorological droughts) can be seen in southeastern and northwestern

16 portion of the country. Decreased meteorological drought intensities or increased precipitation

17 can be at some locations in the east. Null hypothesis of no drought trend could not be rejected

18 over much of the southwestern and northeastern as well as western portions of the nation. Bega

19 rains are critical in the central portions of Ethiopia and the short-term rainfall has either not

20 changed or increased in the west-central portions while statistically significant (0.05 significance

21 level) declining trends can be seen in the east-central sections of the country. 


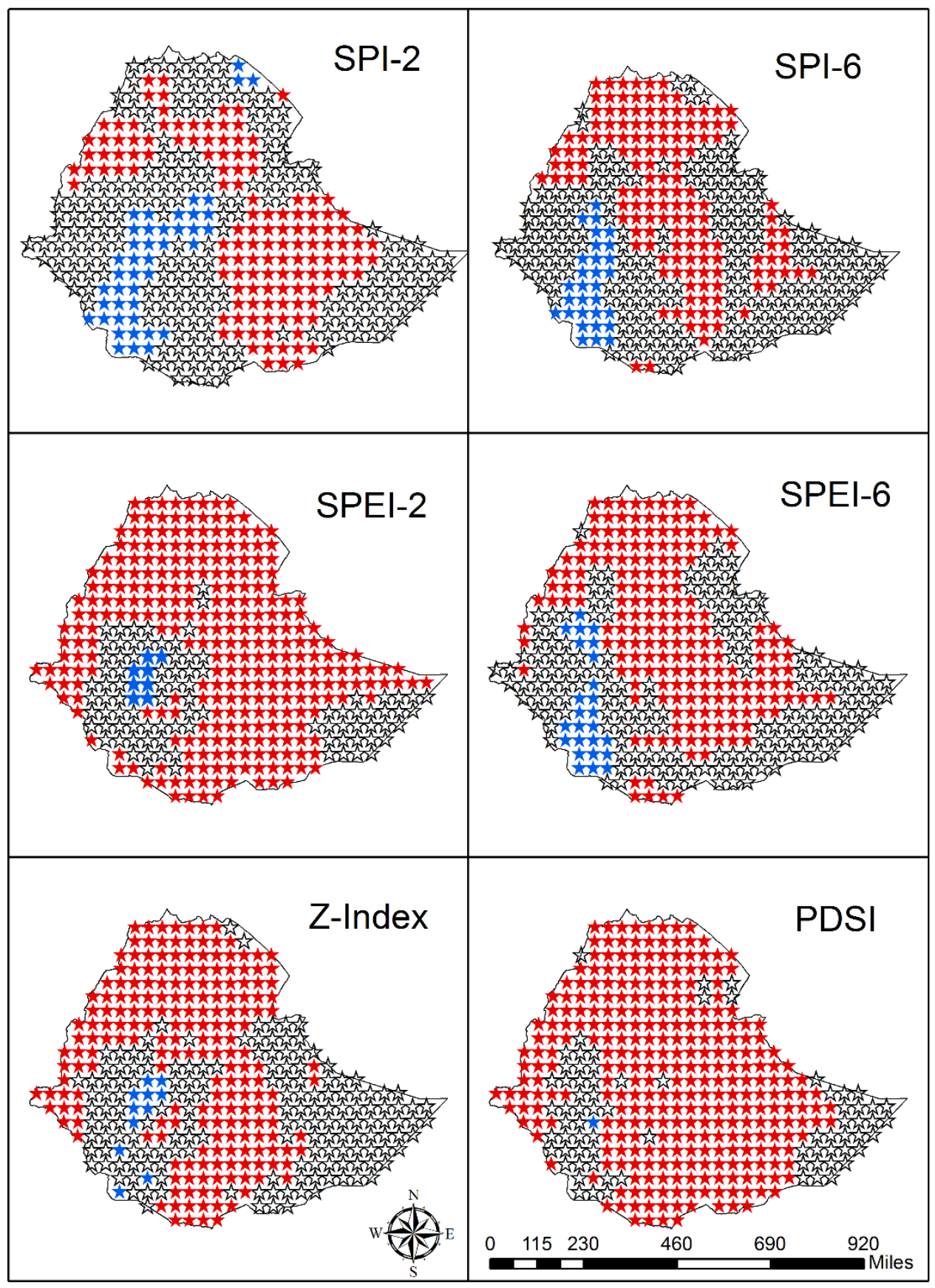

2 Figure 3: Observed Trends in Bega Drought Indicators (Red: Drying Trend, Blue: Wetting Trend and Black - No statistical trend)

5 Many locations that have a wetting SPI-2 trend either have no or exhibit drying trends for SPI-6

6 which accumulates more of Meher and Belg rainfall. This result appears to indicate that some of 
1 the noted increased wetness could be attributable to shifts in precipitation patterns. In a similar

2 vein, there are greater number of wetting trends noted with SPEI-6 than SPEI-2. This result points

3 to likely warming in the winter months (Oct-Jan) which is dampened over a longer-accumulation

4 periods. The PDSI is the most aggressive indicator in terms of predicting long-term agricultural

5 droughts. While Z-index does not point to significant wetting trends, it is unable to discern

6 negative trends in the southeastern portions of the country. SPEI-2 appears to exhibit slightly

7 better statistical power in discerning short-term agricultural droughts in this region season.

9 The magnitude of the observed trend is important to evaluate the rate of progression of observed

10 wetting and drying phenomena. Figure 4 depicts the Sen's slope values for different drought

11 indictors for Bega season. The Sen slope was set to zero when the null hypothesis of no trend

12 could not be rejected. Figure 4 shows that the median magnitude of the Sen's slope was $\sim 0.005$

13 drought units (DU) /y for SPI-2 and 0.01 (DU/y) for SPEI-2 and Z-Index. At least $75 \%$ of the

14 locations exhibited a drying precipitation trend and this number increases considerably for SPEI-

15 2. While Z-index is not aggressive as as SPEI-2 in identifying drying trends, the rate of drying for

16 Z-index exhibits a much larger variability and sometimes more intense then SPEI-2. The results

17 suggest precipitation-induced dryness is increasing at a rate of 5\% per decade while agricultural

18 droughts are intensifying at a rate of $10 \%$ per decade. This implies temperature increases (global

19 warming) on average doubles the intensity of precipitation declines for short-term droughts during 20 Bega. 


\section{Sen Slope for Short-term Drought Indicators}

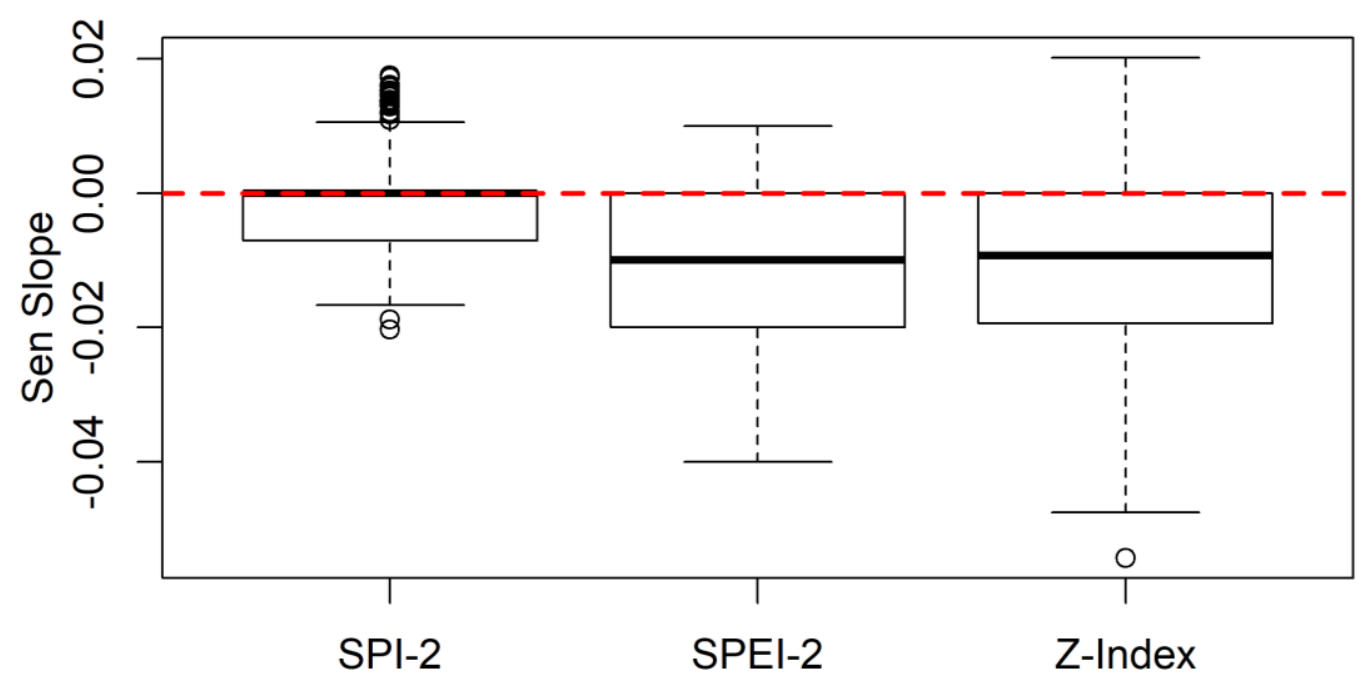

\section{Sen Slope for Long-term Drought Indicators}

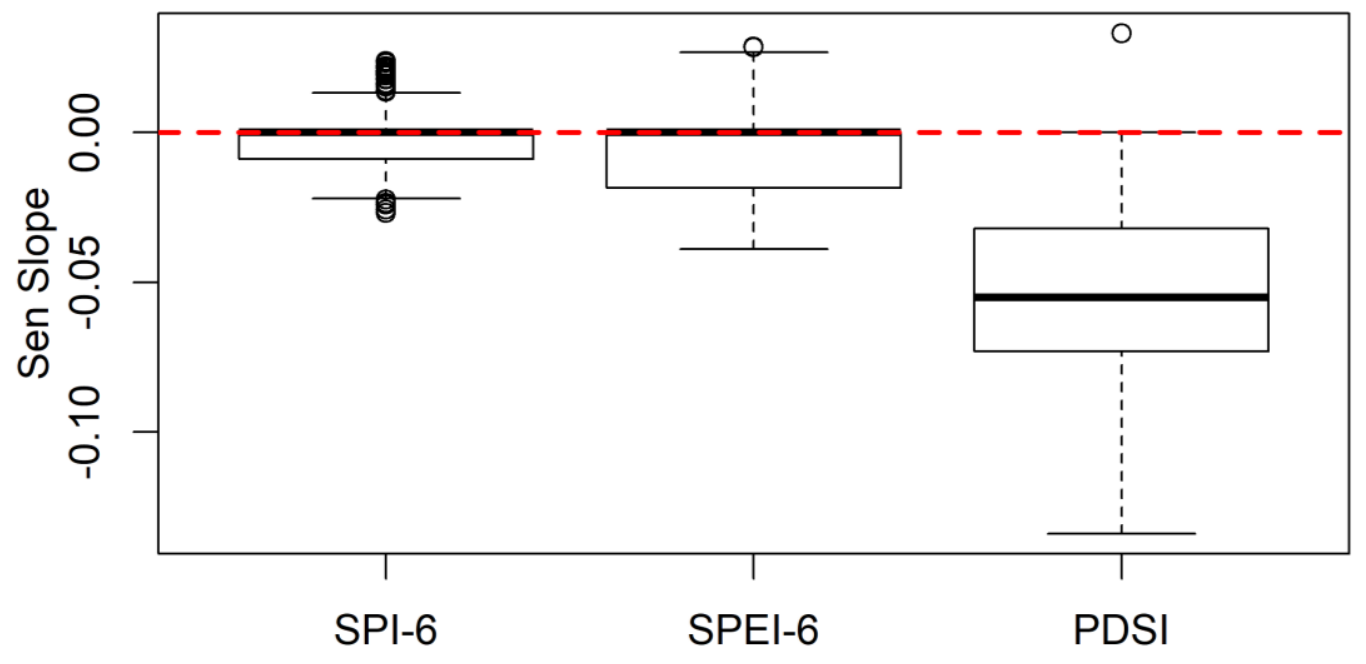

Figure 4: Variability of Sen's Slope for Various Indicators for Bega Season

4 The long-term wetting and drying trends produce a vastly different picture than short-term drying

5 effects. The median precipitation related drying intensity is much smaller $\sim 0.001 \mathrm{DU} / \mathrm{y}$, for SPI- 
16 and only slightly higher for SPEI-2. PDSI on the other hand exhibits a strong drying intensity

2 of $\sim 0.05 \mathrm{DU} / \mathrm{y}$ ( $5 \%$ increase in dryness per year). This result indicates that while surficial dryness

3 arising due to increased atmospheric temperature may not be significant (SPEI-6) it does have a

4 considerable effect on the hydrologic soil water balance as conceptualized and computed by PDSI.

5 The long-term PDSI trends are occurring at an alarming rate. Accurate soil moisture

6 measurements are critical to rigorously validate the trend projections of PDSI. 


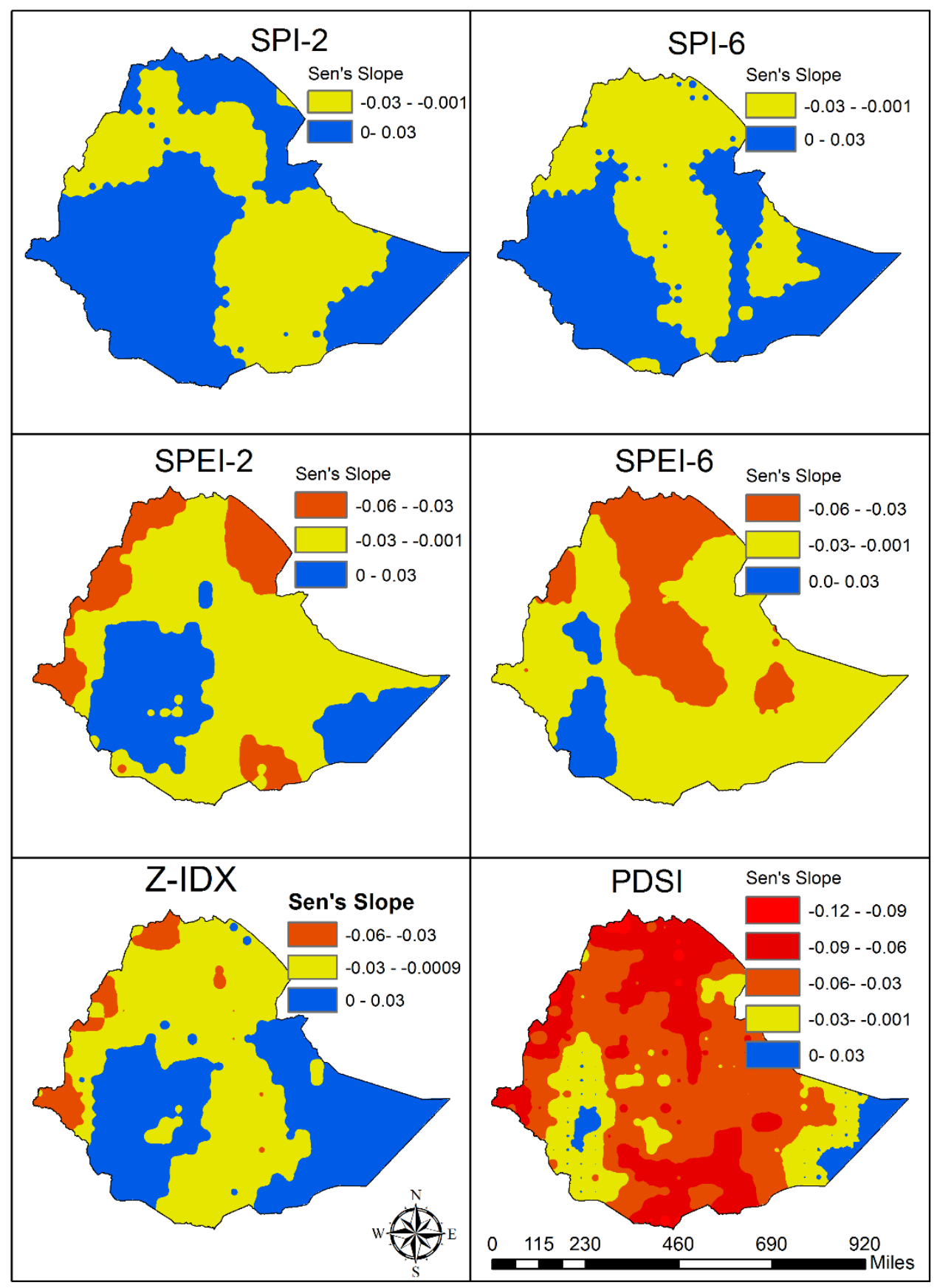

2 Figure 5: Variability of Sen's Slope Across Ethiopia for Various Drought Indicators for Bega Season

5 As to be expected, the magnitudes of wetting and drying trends also exhibit considerable spatial

6 variability. The north and north-central portions of the country are experiencing highest rate of

7 drying intensity compared to eastern and western portions of the country. Short-term Bega 
1 precipitation deficits (as denoted by SPI-2) appear to transition from a wetting to a drying trend

2 moving west to east across the Rift Valley. It can also be seen that the trend variability is not

3 uniform across the indicators with PDSI and Z-index showing much different trends than SPI and

4 SPEI based indicators. This result highlights the fact that a single indicator does not provide the

5 complete picture of the droughts during Bega.

6 Trends across Ethiopia during Belg Season:

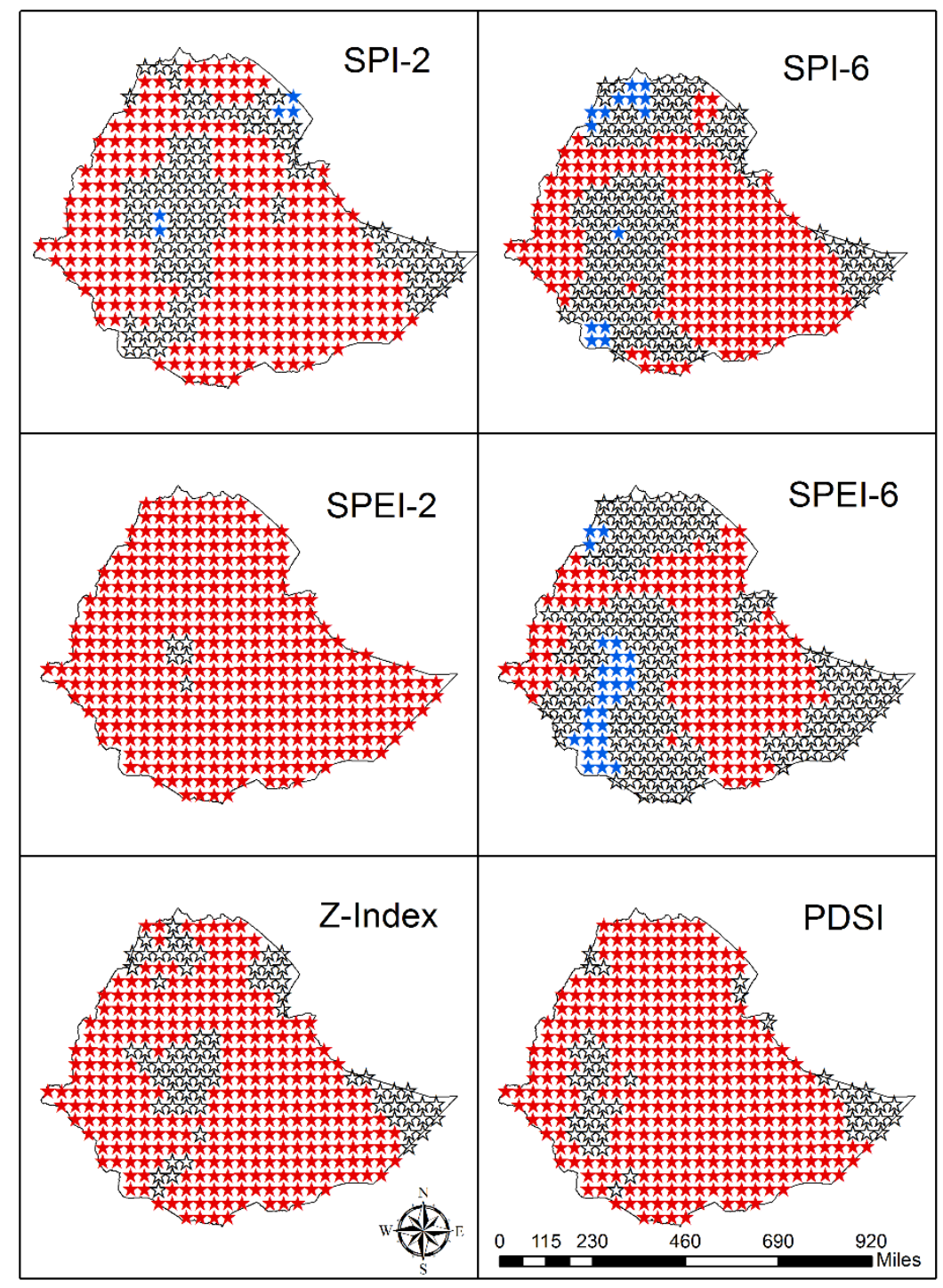

8 Figure 6: Trends for Various Drought Indicators Across Ethiopia for Belg Season (Red: Drying $9 \quad$ Trends and Blue: Wetting Trends, Black: No Trends 
1

2 Figure 6 indicates that drying trends are most prevalent during Belg season especially in-

11 A comparison of SPI-2 and SPEI-2 indicates that many areas where SPI-2 (precipitation) had

12 discerned no trend appear to show declining trends under SPEI-2 indicating that increased

13 temperatures is likely an important mechanism for controlling intra-seasonal droughts. However,

14 as declining SPI-2 (precipitation) trends can be seen across Ethiopia, precipitation declines during

15 this season also exert a considerable amount of influence on short-term agricultural droughts. The

16 SPEI-6 shows lesser drying trends and even some wetting trends compared to SPI-6 this result

17 indicates that SPEI-6 carries over the effects of Belg and Mehir more so than SPI-6. The small

18 section in the northern portion where SPI-6 shows wetting trend is masked by temperature effect

19 of SPEI (resulting in no SPEI-6 trends in that area). However, some areas where precipitation has

20 not changed (no trends in SPI) are marked as positive (wetting) trends by SPEI-6, especially in the

21 south and south-central portions of Ethiopia. This result points to a likely cooling effect (during

22 Belg and late Mehir seasons likely due to increased humidity and cloud cover) in these portions of

23 the country which SPEI-6 is able to capture in terms of reduced PET. As, with Belg (Figure 3) the

24 Z-index and PDSI exhibit drought patterns that are considerably different from SPI and SPEI. 
1 While Z-index may be somewhat buffered by soil moisture storage in some pockets of the country

2 (where no trends are detected), the PDSI trends indicate that this storage is short-lived and not 3 sustained over the entire growing season due to the effects of hydrological processes that remove 4 water from the soil column.

6 Belg season is important for growing Tef (Eragrostis Tef) which is a staple food and empirical 7 evidence of farmers unable to harvest their crops during this season has been discussed by Rossel 8 and Holmer [58]. As Tef grown during Belg is mostly consumed internally, agricultural droughts 9 during Belg has profound implications to the food security and livelihoods of Ethiopia.

10 Furthermore, if the production of Tef is shifted to the longer Mehir season, the growth of high 11 valued (export-oriented) crops comes under threat affecting the economic viability of the nation 12 which depends extensively on agricultural production.

14 The Sen's slope values are much higher in magnitude when compared to Bega season. The median 15 drop rate is $\sim 0.01 \mathrm{DU} / \mathrm{y}$ for SPI-2, $\sim 0.03 \mathrm{DU} / \mathrm{y}$ for SPEI-2 and $\sim 0.02 \mathrm{DU} / \mathrm{y}$ for Z-index. At these 16 historical rates, the intra-seasonal drought indicators are changing (declining) on average) by $10 \%$

$17-30 \%$ over a decade. In a similar manner the changes in SPI-6 ( 0.01 DU/y), SPEI-6 ( 0.00 DU/y) 18 and PDSI $\sim 0.06$ (DU/y). The median changes in short-term and long-term SPI are roughly the

19 same, there is an improvement in SPEI, and PDSI changes are most drastic over all indicators.

20 The declines in precipitation during Belg, especially in relation to Bega stands out and the declines

21 in precipitation plays a much greater role in defining agricultural droughts in this season. 


\section{Sen Slope for Short-term Drought Indicators}

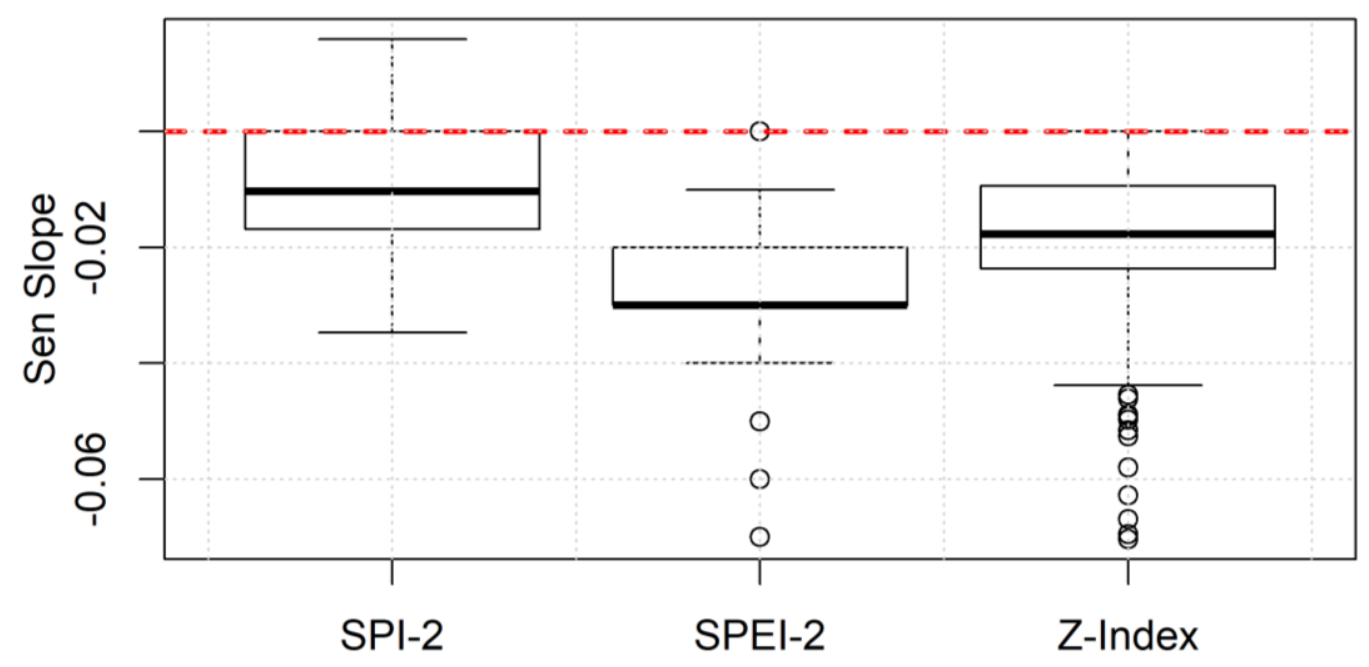

Sen Slope for Long-term Drought Indicators

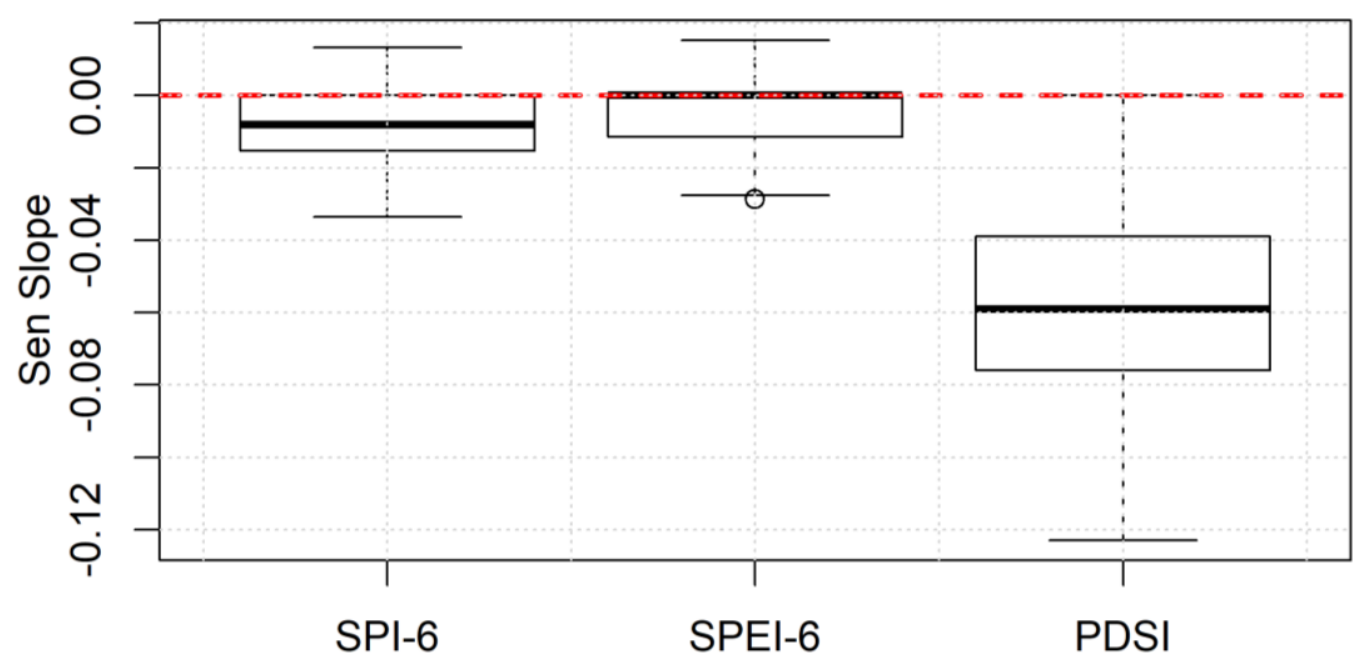

1

2 Figure 7: Variability in Sen's Slope for Various Drought Indicators Across Ethiopia during Belg 3 Season (Sen Slope was set zero when there was no trend detected) 
1 The variability of Sen's slope for various drought indicators during Belg season is shown in Figure

2 8. Areas along the eastern border (Sudan and South Sudan) are generally seeing increased dryness

3 in both short-term and long-term trends. This drying along the Sudan border will likely exacerbate

4 already existing water resources conflicts, especially the sharing of transboundary rivers such as

5 Blue Nile between Ethiopia and her neighbors. Increased dryness can be seen across the east

6 central portions again across all indicators, albeit with different intensities. This area includes

7 cities such as Dira Dawa and Dolo Odo which are critical for the development of eastern Ethiopia.

8 All in all, both meteorological and agricultural droughts have increased over the last century. This

9 declining trend in conjunction with a rapidly increasing population and limited irrigation systems

10 has profound implications on the future food security of the nation and highlights the need for

11 improved irrigation systems to build resilience into Ethiopian agricultural systems. 


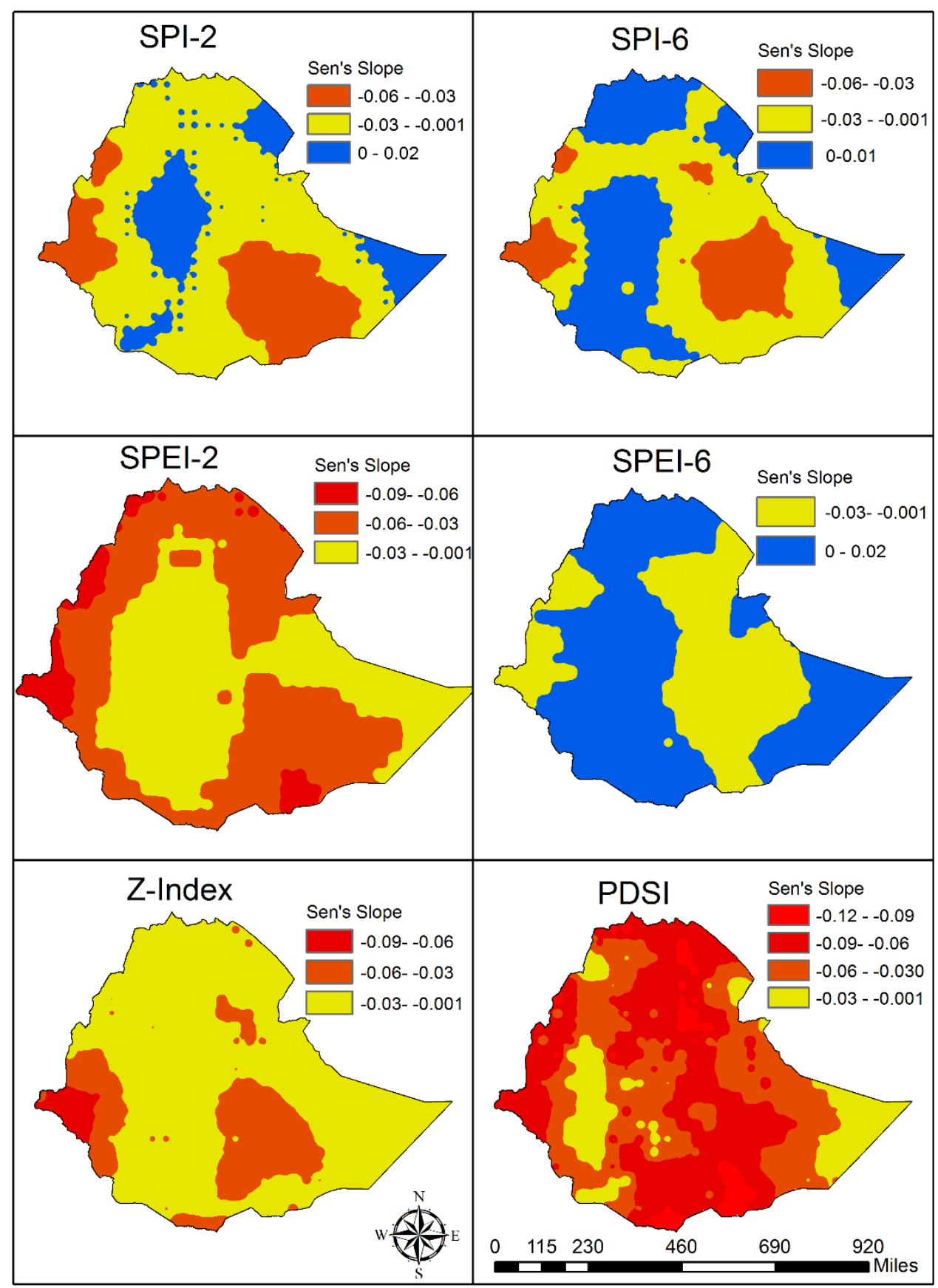

2 Figure 8: Variation in Sen's Slope Across Ethiopia for Various Drought Indicators for Belg 3 Season 
1 Trends across Ethiopia during Meher Season:

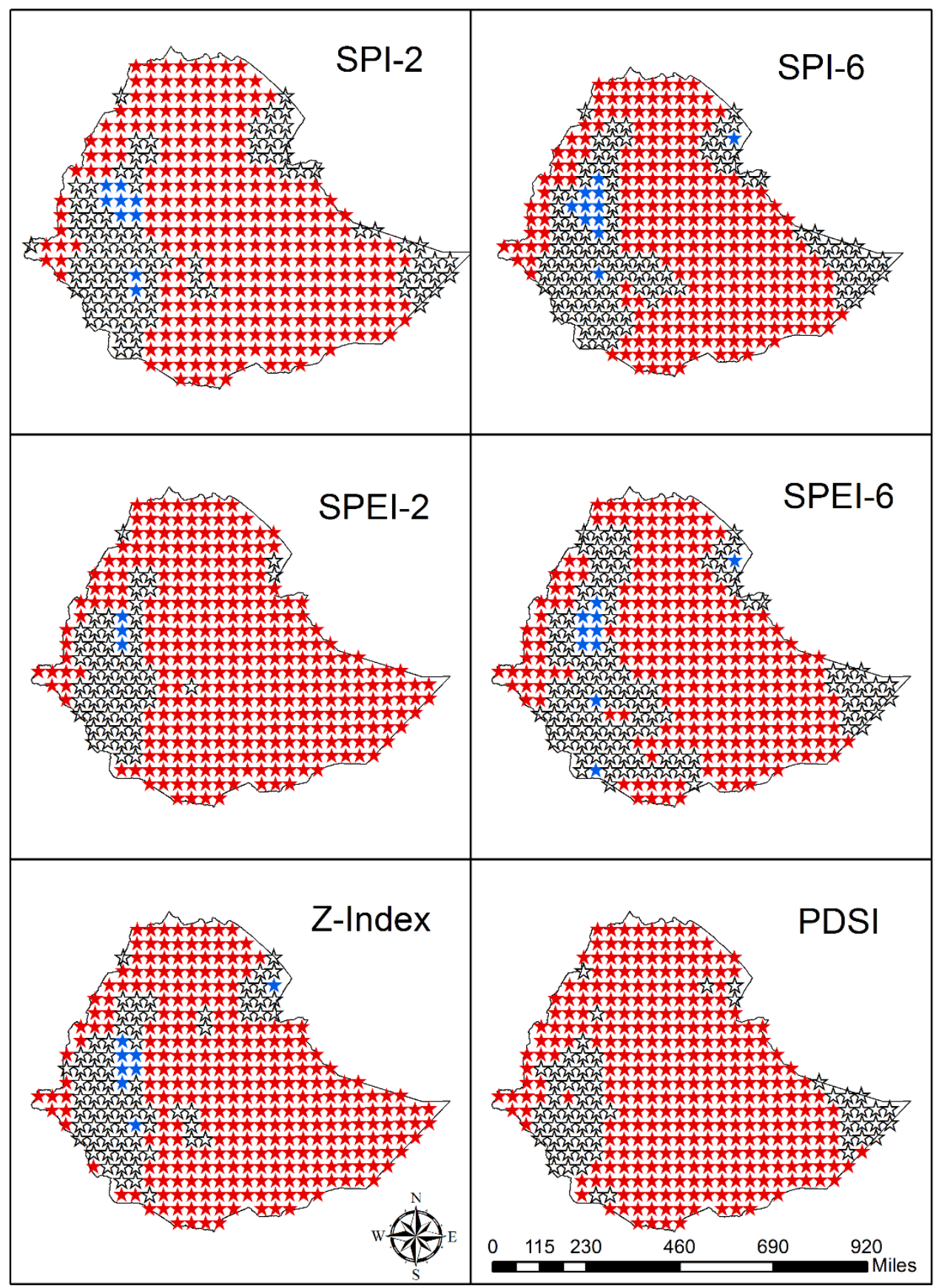

$3 \quad$ Figure 9: Trends Across Ethiopia during Meher Season for various Drought Indicators 
1 Rainfall during Meher season is caused by the convergence of low-pressure systems and the inter

2 tropical convergence zone (ITCZ). This is the main rainy season across most of the Ethiopia where

3 majority of crops are grown. Figure 9 shows the trends of various drought indictors across Ethiopia

4 during Meher season. Again, significant drying trends both due to precipitation declines as well

5 as warming can be seen over large parts of the country. A few locations do exhibit increasing

6 rainfall trends (see SPI maps) which is dwarfed by changes in temperature (see SPEI maps).

7 Warming effects can be noticed both in short-term and long-term drought indicators. Again, SPEI-

82 is the most aggressive of all short-term drought indicators while PDSI exhibits greatest

9 sensitivity to predicting long-term droughts. As rainfall during this season is mainly derived from

10 ITCZ, the narrowing of ITCZ noted over the last century [59] could perhaps explain some of the

11 noted increased dryness. Seleshi and Zanke [9] also indicate that warm El Niño-southern 12 oscillation episodes correlate well with declines in June-September rainfall over the Ethiopian 13 Highlands.

15 The magnitude of median Sen's slope is $\sim 0.018$ DU/y for SPI-2 and around 0.02 DU/y for SPEI-

162 and Z-index indicating that temperature changes due to global warming exacerbate the dryness

17 induced by precipitation declines for most part of Ethiopia (Figure 10). For long-term droughts,

18 SPI-6 and SPEI-6 have a median Sen's slope of $\sim 0.01$ DU/y while PDSI has a value of about 0.06

19 DU/y (see Figure 10). Indicating a 1\% - 6\% increase in dryness on average across the country

20 comparable to noted changes in Belg. The short-term dryness during Meher Season is dampened

21 by precipitation from other seasons which factor in long-term meteorological and agricultural

22 drought calculations. Comparison of short-term drought indicators of Meher (Figure 11) against

23 those during Bega (Figure 3) appears to indicate that some areas that exhibit declining trends 
1 during Meher exhibit increased SPI-2 during Bega, likely pointing towards shifts in late-season

2 precipitation of Meher into Bega. While the noted drying trends during Meher are not as strong

3 as those during other seasons, they are nonetheless significant as Meher is the major rainy season

4 which accounts for more than $50 \%$ of the annual rainfall of the country. Therefore, even small

5 changes in trend can imply significant changes in terms of precipitation declines. Funk et al. [20]

6 report $50 \mathrm{~mm}-150 \mathrm{~mm}$ declines in Kremit (Meher) rainfall over the last 50 year period which

7 represents a significant proportion of water needs for many crops that are grown during the Meher 8 season. 


\section{Sen Slope for Short-term Drought Indicators}

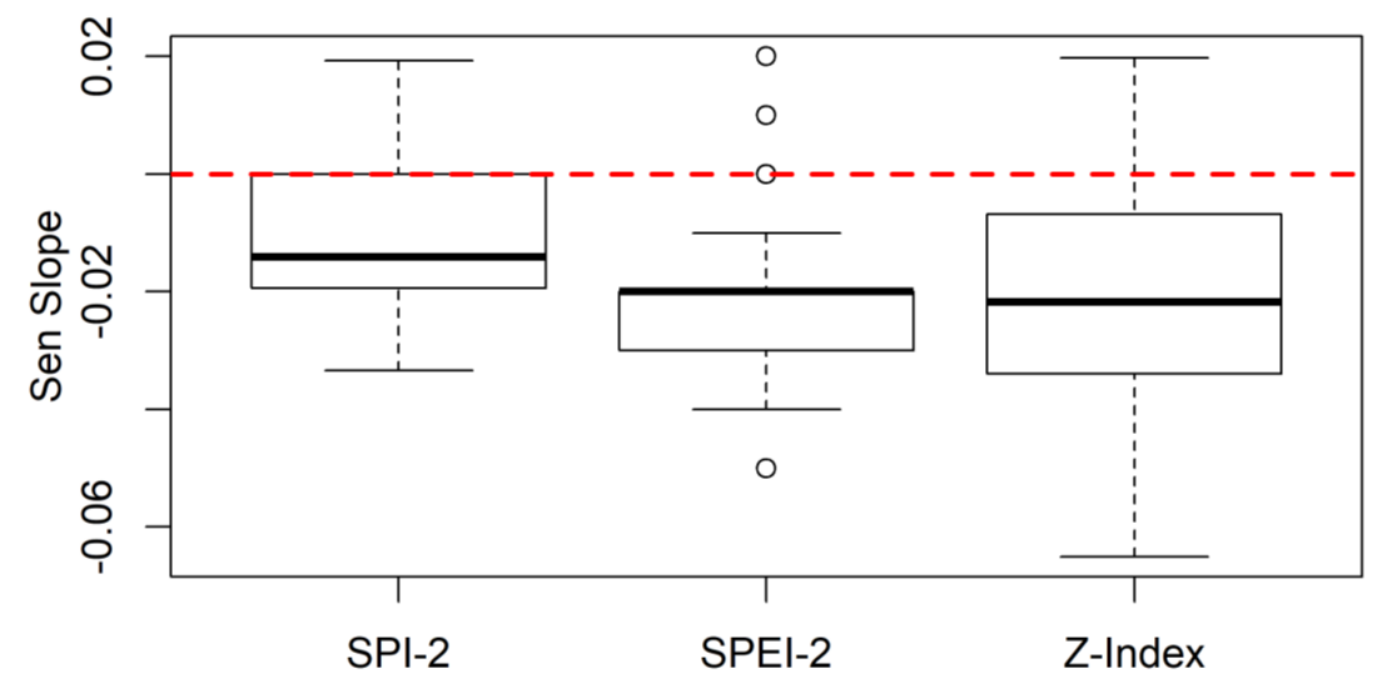

Sen Slope for Long-term Drought Indicators

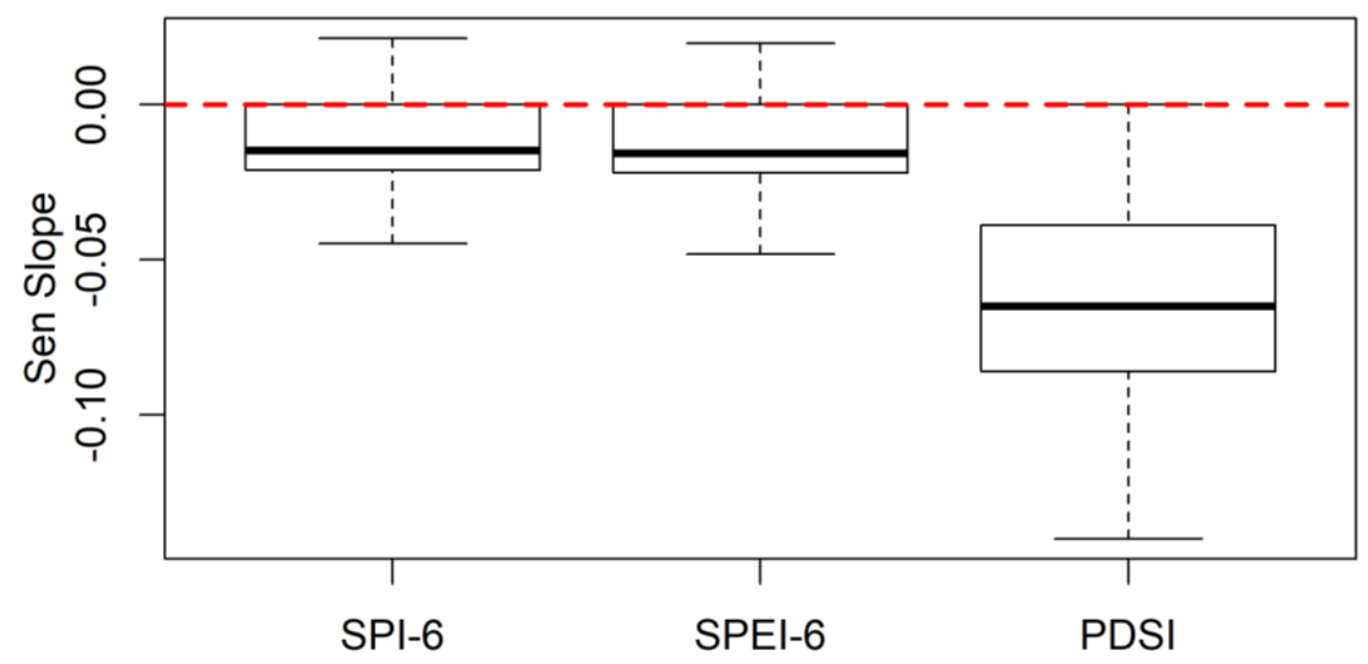

2 Figure 10: Variability of Sen's Slope Across Short-term and Long-term Drought Indicators 


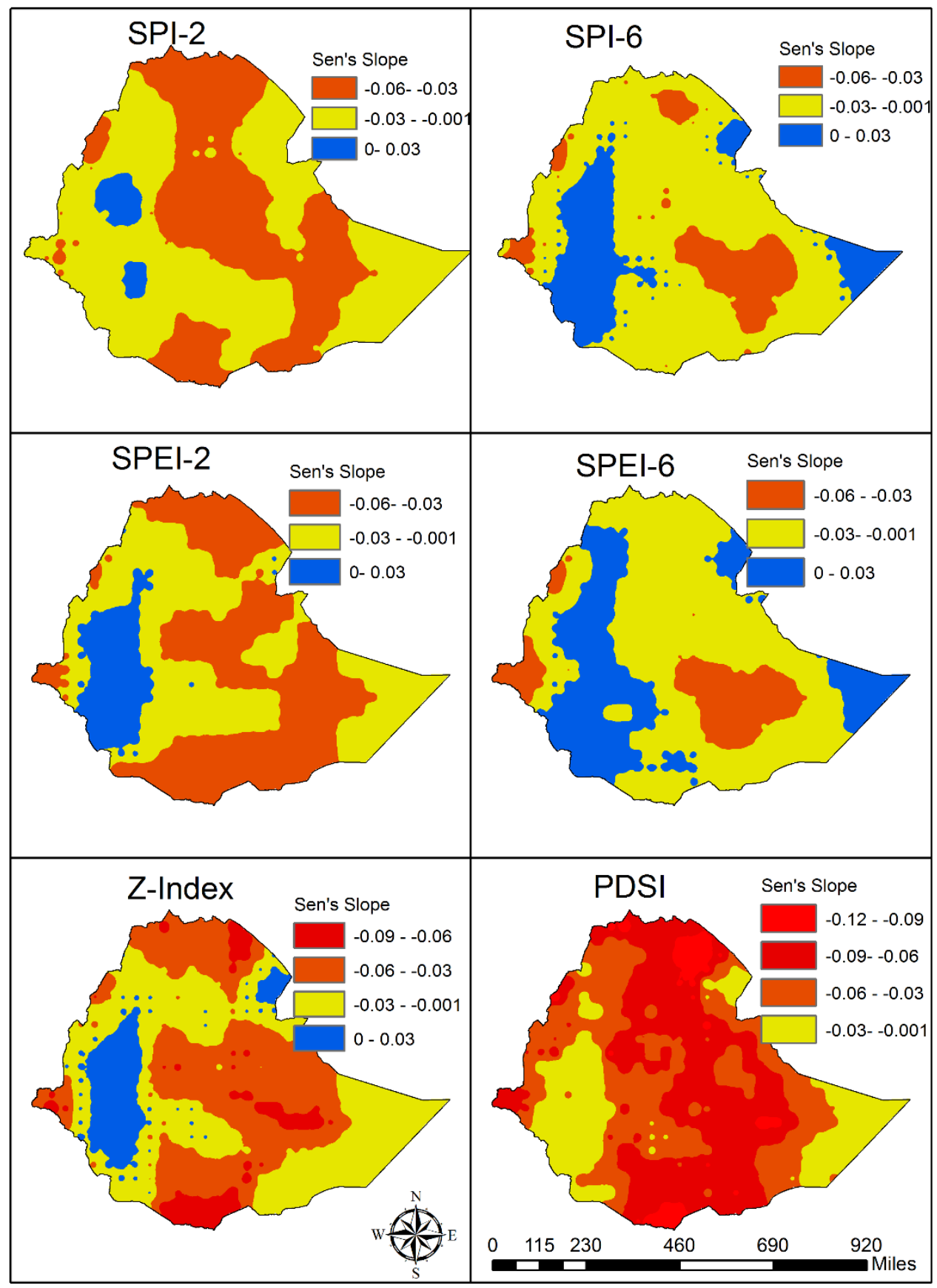

Figure 11: Variability of Sen's Slope Across Ethiopia for Various Drought Indicators

4 The spatial variability in drought indicators for Meher season (mapped in Figure 11) again points

5 to the east-central band that runs across the nation. Changes in drought indicators are prominent

6 along the Ethiopia-Eretria border but relatively subdued along the eastern borders with Sudan 
1 and South Sudan. Nonetheless, the contributions of Blue Nile to overall flow of Nile is over

$280 \%$ during the Meher season and even small declines in precipitation trends in the catchment

3 area can have profound implications on these streamflows.

4

5 The drying trends noted due to precipitation declines and temperature increases in the central parts

6 of the country $\left(37.5^{\circ} \mathrm{E}-42.5^{\circ} \mathrm{E}\right)$ places greater risk on agricultural production of the nation as a

7 significant portion of agricultural lands and rangelands lie in this portion of the country (see Figure

8 1c). High valued crops such as corn are grown during this season and increasing drying trends in

9 major agricultural producing regions significantly increases the risk to food and economic security

10 of the nation.

12 Closing Remarks

13 As a rainfall dependent country, droughts can cause major economic, environmental and

14 sociopolitical disruptions in Ethiopia. Agricultural is the primary economic driver in Ethiopia,

15 understanding how meteorological droughts propagate through agricultural systems is of

16 paramount importance. Given most agriculture systems are rainfed, there has been many studies

17 that have evaluated regional trends in the Standardized Precipitation Index (SPI). However, in

18 addition to rainfall, soil dryness caused by increased temperatures (global warming) also

19 influences soil moisture (the master variable for defining agricultural droughts). Drought

20 indicators that account for both precipitation and temperature effects are therefore better suited for

21 quantifying agricultural droughts. In this study, the Standardized Precipitation Evapotranspiration

22 Index (SPEI) and the Palmer Drought Severity Index (PDSI) and the associated Z-index are used 
1 to characterize short-term ( 2 month accumulation) and long-term (6 month accumulation) droughts

2 during the three major seasons (Bega, Belg and Meher) in Ethiopia.

4 The results consistently indicate that SPEI-2 (two-month accumulation) was the most aggressive 5 drought indicator for characterizing short-term droughts indicating surficial drying due to 6 increased temperatures are important in characterizing short-term agricultural droughts. Intra-

7 seasonal droughts over much of the country exhibited declining trends when evaluated on a 8 century-scale (1902 - 2016). Increased winter temperatures had a major influence on Bega 9 rainfalls. Temperature increases further exacerbated noted precipitation declines during Belg and

10 Meher two important growing seasons in Ethiopia. In terms of rate changes, increased dryness is

11 most pronounced during Belg (short-growing season). While the rate changes are relatively lower

12 during Meher, the changes in the magnitude of precipitation is more as this is the major rainy 13 season over much of Ethiopia.

15 Long-term (6-months) drought indicators typically had a slightly subdued response than short16 term intra-season droughts but similar trends noted over the short-term also manifested in the long17 term for the most part. The subdued long-term signals arise because rainfall in other seasons that 18 get accumulated in the longer-term droughts, help buffer intra-seasonal changes. PDSI was noted

19 to be the most assertive drought indicator for long-term droughts indicating that noted precipitation

20 and temperature declines create a delayed but more prominent changes in hydrologic and soil 21 moisture dynamics that other indicators (SPI and SPEI) do not capture fully in their 22 conceptualizations. 
1 Increased dryness trends during Belg were noted along the eastern borders of Ethiopia with Sudan

2 and South Sudan. These changes have the potential to increase the contentious transboundary

3 water sharing conflicts that already exist between these nations. A band approximately between

$4 \quad\left(37.5^{\circ} \mathrm{E}-42.5^{\circ} \mathrm{E}\right)$ is a climate hot-spot where significant percent of the Ethiopia population resides

5 and practices agricultural and pastoral activities. The increased dryness coupled with exponential

6 population growth places an enormous stress on the agricultural systems of the country which are

7 generally not buffered by blue water (irrigation) supplements.

9 The results of the study indicate that climate has changed considerably over the last century in

10 Ethiopia which in turn has affected the drought characteristics. Agricultural systems are affected

11 by short-term soil drying during increased temperatures. Hydrologic changes caused by

12 precipitation declines and temperature increases act slowly but affect soil moisture availability

13 over the growing season. Comparison of multiple drought indicators suggests that precipitation-

14 based SPI, while useful does not provide a complete picture of long-term drought trends noted in

15 Ethiopia. Temperature increases tend to negate precipitation increases noted in some parts of the

16 country. Therefore, it is recommended that multiple drought indicators be used during water

17 policy planning and management endeavors. The creation of a national-scale soil moisture sensing

18 program (along with other factors that help conduct soil water budgets) should be a top-priority

19 for sustaining rainfed agricultural dependent economy of Ethiopia 
2 We thank the Ministry of Education, Government of Ethiopia and the Jimma Institute of

3 Technology for extending their support to this research. The logistic support provided by Dr.

4 Job Kasule is also gratefully acknowledged.

5 Author Contributions

6 Conceptualization, Venkatesh Uddameri and Elma Hernandez; Data curation, Dawd Temam and

7 Ghazal Mohammadi; Formal analysis, Dawd Temam; Funding acquisition, Stephen Ekwaro-

8 Osire; Investigation, Dawd Temam; Methodology, Venkatesh Uddameri; Project administration,

9 Stephen Ekwaro-Osire; Software, Venkatesh Uddameri; Supervision, Venkatesh Uddameri;

10 Validation, Elma Hernandez; Visualization, Dawd Temam; Writing - original draft, Venkatesh

11 Uddameri; Writing - review \& editing, Ghazal Mohammadi, Elma Hernandez and Stephen

12 Ekwaro-Osire.

13 References

14 1. Ewonetu, G. Identifing Major Constraints of Ground Water Use for Irrigated Crop Production:

15 Fogera Plain, North Western Ethiopia. Cornell University: 2012.

2. MoA (Ministry of Agriculture). Small-Scale Irrigation Situation Analysis and Capacity Needs Assessment; Natural Resource Management and Regulatory Department: Addis Ababa, Ethiopia: 2011.

3. McCann, J.C. A Great Agrarian Cycle? Productivity in Highland Ethiopia, 1900 to 1987. The Journal of Interdisciplinary History 1990, 20, 389-416, doi:10.2307/204084.

5. Mersha, A.A.; van Laerhoven, F. The interplay between planned and autonomous adaptation in response to climate change: Insights from rural Ethiopia. World Development 2018, 107, 87-97, doi:10.1016/j.worlddev.2018.03.001.

31

6. Wagesho, N.; Goel, N.K.; Jain, M.K. Temporal and spatial variability of annual and seasonal rainfall over Ethiopia. Hydrological Sciences Journal 2013, 58, 354-373, 
doi:10.1080/02626667.2012.754543.

7. Korecha, D.; Sorteberg, A. Validation of operational seasonal rainfall forecast in Ethiopia. Water Resources Research 2013, 49, 7681-7697, doi:10.1002/2013WR013760.

8. Dinku, T.; Connor, S.J.; Ceccato, P.; Ropelewski, C.F. Comparison of global gridded precipitation products over a mountainous region of Africa. International Journal of Climatology 2008, 28, 1627-1638, doi:10.1002/joc.1669.

9. Seleshi, Y.; Zanke, U. Recent changes in rainfall and rainy days in Ethiopia. International Journal of Climatology 2004, 24, 973-983, doi:10.1002/joc.1052.

10. Ofcansky, T.P., Laverle B.B. Ethiopia: a country study; Federal Research Division: Washington, D.C.:1991.

11. Verdin, J.; Funk, C.; Senay, G.; Choularton, R. Climate science and famine early warning. Philosophical Transactions of the Royal Society B: Biological Sciences 2005, 360, 2155-2168, doi:10.1098/rstb.2005.1754.

12. Mekuyie, M.; Jordaan, A.; Melka, Y. Understanding resilience of pastoralists to climate change and variability in the Southern Afar Region, Ethiopia. Climate Risk Management 2018, 20, 64-77, doi:10.1016/j.crm.2018.02.004.

13. Megersa, B.; Markemann, A.; Angassa, A.; Valle Zárate, A. The role of livestock diversification in ensuring household food security under a changing climate in Borana, Ethiopia. Food Security 2014, 6, 15-28, doi:10.1007/s12571-013-0314-4.

14. Degefu, M.A.; Bewket, W. Trends and spatial patterns of drought incidence in the omo-ghibe river basin, ethiopia. Geografiska Annaler: Series A, Physical Geography 2015, 97, 395-414, doi:10.1111/geoa.12080.

15. Edossa, D.C.; Babel, M.S.; Das Gupta, A. Drought Analysis in the Awash River Basin, Ethiopia. Water Resources Management 2010, 24, 1441-1460, doi:10.1007/s11269-009-9508-0.

16. Seleshi, Y.; Camberlin, P. Recent changes in dry spell and extreme rainfall events in Ethiopia. Theoretical and Applied Climatology 2006, 83, 181-191, doi:10.1007/s00704-005-0134-3.

17. Bewket, W.; Conway, D. A note on the temporal and spatial variability of rainfall in the droughtprone Amhara region of Ethiopia. International Journal of Climatology 2007, 27, 1467-1477, doi:10.1002/joc.1481.

18. Cheung, W.H.; Senay, G.B.; Singh, A. Trends and spatial distribution of annual and seasonal rainfall in Ethiopia. International Journal of Climatology 2008, 28, 1723-1734, doi:10.1002/joc.1623.

19. Rientjes, T.H.M.; Haile, A.T.; Kebede, E.; Mannaerts, C.M.M.; Habib, E.; Steenhuis, T.S. Changes in land cover, rainfall and stream flow in Upper Gilgel Abbay catchment, Blue Nile basin - 
Ethiopia. Hydrology and Earth System Sciences 2011, 15, 1979-1989, doi:10.5194/hess-15-19792011.

20. Funk, C.; Rowland, J.; Eilerts, G.; Kebebe, E.; Biru, N.; White, L.; Galu, G. A climate trend analysis of Ethiopia. US Geological Survey, Fact Sheet 2012, 3053.

21. Viste, E.; Korecha, D.; Sorteberg, A. Recent drought and precipitation tendencies in Ethiopia. Theoretical and Applied Climatology 2013, 112, 535-551, doi:10.1007/s00704-012-0746-3.

22. Wondie, M.; Terefe, T. Assessment of drought in Ethiopia by using self-calibrated Palmer Drought Severity Index. International Journal of Engineering, Management and Sciences 2016, 7, 108-117.

23. Bekele, D.; Alamirew, T.; Kebede, A.; Zeleke, G.; Melese, A.M. Analysis of rainfall trend and variability for agricultural water management in Awash River Basin, Ethiopia. Journal of Water and Climate Change 2016, 8, 127-141, doi:10.2166/wcc.2016.044.

24. Abebe, G. Long-term climate data description in Ethiopia. Data in brief 2017, 14, 371-392, doi:10.1016/j.dib.2017.07.052.

25. Suryabhagavan, K.V. GIS-based climate variability and drought characterization in Ethiopia over three decades. Weather and Climate Extremes 2017, 15, 11-23, doi:10.1016/j.wace.2016.11.005.

26. Asfaw, A.; Simane, B.; Hassen, A.; Bantider, A. Variability and time series trend analysis of rainfall and temperature in northcentral Ethiopia: A case study in Woleka sub-basin. Weather and Climate Extremes 2018, 19, 29-41, doi:10.1016/j.wace.2017.12.002.

27. Easterling, D.R.; Evans, J.L.; Groisman, P.Y.; Karl, T.R.; Kunkel, K.E.; Ambenje, P. Observed Variability and Trends in Extreme Climate Events: A Brief Review. Bulletin of the American Meteorological Society 2000, 81, 417-426, doi:10.1175/15200477(2000)081<0417:OVATIE >2.3.CO;2.

28. Keyantash, J.; Dracup, J.A. The Quantification of Drought: An Evaluation of Drought Indices. Bulletin of the American Meteorological Society 2002, 83, 1167-1180, doi:10.1175/1520-047783.8.1167.

29. Mishra, A.K.; Singh, V.P. A review of drought concepts. Journal of Hydrology 2010, 391, 202-216, doi:10.1016/j.jhydrol.2010.07.012.

30. Wells, N.; Goddard, S.; Hayes, M.J. A Self-Calibrating Palmer Drought Severity Index. Journal of Climate 2004, 17, 2335-2351, doi:10.1175/1520-0442(2004)017<2335:ASPDSI>2.0.CO;2.

31. Karl, T.R. The Sensitivity of the Palmer Drought Severity Index and Palmer's Z-Index to their Calibration Coefficients Including Potential Evapotranspiration. Journal of Climate and Applied Meteorology 1986, 25, 77-86, doi:10.1175/1520-0450(1986)025<0077:TSOTPD>2.0.CO;2.

32. Vicente-Serrano, S.M.; Beguería, S.; López-Moreno, J.I. A Multiscalar Drought Index Sensitive to Global Warming: The Standardized Precipitation Evapotranspiration Index. Journal of Climate 
33. Potop, V. Evolution of drought severity and its impact on corn in the Republic of Moldova. Theoretical and Applied Climatology 2011, 105, 469-483, doi:10.1007/s00704-011-0403-2.

34. Wang, D.; Hejazi, M.; Cai, X.; Valocchi, A.J. Climate change impact on meteorological, agricultural, and hydrological drought in central Illinois. Water Resources Research 2011, 47, doi:10.1029/2010WR009845.

35. Zambreski, Z.T.; Lin, X.; Aiken, R.M.; Kluitenberg, G.J.; Pielke Sr, R.A. Identification of hydroclimate subregions for seasonal drought monitoring in the U.S. Great Plains. Journal of Hydrology 2018, 567, 370-381, doi:10.1016/j.jhydrol.2018.10.013.

36. Karamouz, M.; Rasouli, K.; Nazif, S. Development of a Hybrid Index for Drought Prediction: Case Study. Journal of Hydrologic Engineering 2009, 14, 617-627, doi:10.1061/(ASCE)HE.19435584.0000022.

37. Sepulcre-Canto, G.; Horion, S.; Singleton, A.; Carrao, H.; Vogt, J. Development of a Combined Drought Indicator to detect agricultural drought in Europe. Natural Hazards and Earth System Sciences 2012, 12, 3519-3531, doi:10.5194/nhess-12-3519-2012.

38. Ziese, M.; Schneider, U.; Meyer-Christoffer, A.; Schamm, K.; Vido, J.; Finger, P.; Bissolli, P.; Pietzsch, S.; Becker, A. The GPCC Drought Index - a new, combined and gridded global drought index. Earth System Science Data 2014, 6, 285-295, doi:10.5194/essd-6-285-2014.

39. Uddameri, V.; Singaraju, S.; Hernandez, E.A. Is Standardized Precipitation Index (SPI) a Useful Indicator to Forecast Groundwater Droughts? - Insights from a Karst Aquifer. JAWRA Journal of the American Water Resources Association 2019, 55, 70-88, doi:10.1111/1752-1688.12698.

40. Hernandez, E.A.; Uddameri, V. Standardized precipitation evaporation index (SPEI)-based drought assessment in semi-arid south Texas. Environmental Earth Sciences 2014, 71, 2491 2501, doi:10.1007/s12665-013-2897-7.

41. Schneider, U.; Finger, P.; Meyer-Christoffer, A.; Rustemeier, E.; Ziese, M.; Becker, A. Evaluating the Hydrological Cycle over Land Using the Newly-Corrected Precipitation Climatology from the Global Precipitation Climatology Centre (GPCC). Atmosphere 2017, 8, doi:10.3390/atmos8030052.

42. Harris, I.; Jones, P.D.; Osborn, T.J.; Lister, D.H. Updated high-resolution grids of monthly climatic observations - the CRU TS3.10 Dataset. International Journal of Climatology 2014, 34, 623-642, doi:10.1002/joc.3711.

43. Becker, A.; Finger, P.; Meyer-Christoffer, A.; Rudolf, B.; Schamm, K.; Schneider, U.; Ziese, M. A description of the global land-surface precipitation data products of the Global Precipitation Climatology Centre with sample applications including centennial (trend) analysis from 1901present. Earth System Science Data 2013, 5, 71-99, doi:10.5194/essd-5-71-2013. 
44. Stagge, J.H.; Tallaksen, L.M.; Gudmundsson, L.; Van Loon, A.F.; Stahl, K. Candidate Distributions for Climatological Drought Indices (SPI and SPEI). International Journal of Climatology 2015, 35, 4027-4040, doi:10.1002/joc.4267.

45. Dai, A. Characteristics and trends in various forms of the Palmer Drought Severity Index during 1900-2008. Journal of Geophysical Research: Atmospheres 2011, 116, doi:10.1029/2010JD015541.

46. Liu, X.; Zhu, X.; Pan, Y.; Bai, J.; Li, S. Performance of different drought indices for agriculture drought in the North China Plain. Journal of Arid Land 2018, 10, 507-516, doi:10.1007/s40333018-0005-2.

47. Hamed, K.H.; Rao, A.R. A modified Mann-Kendall trend test for autocorrelated data. Journal of Hydrology 1998, 204, 182-196, doi:10.1016/S0022-1694(97)00125-X.

48. Yue, S.; Pilon, P.; Cavadias, G. Power of the Mann-Kendall and Spearman's rho tests for detecting monotonic trends in hydrological series. Journal of Hydrology 2002, 259, 254-271, doi:10.1016/S0022-1694(01)00594-7.

49. Rao, A.R.; Hamed, K.H.; Chen, H.-L. Time domain analysis. In Nonstationarities in Hydrologic and Environmental Time Series, Springer: 2003; pp. 27-55.

50. Yue, S.; Wang, C. The Mann-Kendall Test Modified by Effective Sample Size to Detect Trend in Serially Correlated Hydrological Series. Water Resources Management 2004, 18, 201-218, doi:10.1023/B:WARM.0000043140.61082.60.

51. Khaliq, M.N.; Ouarda, T.B.M.J.; Gachon, P.; Sushama, L.; St-Hilaire, A. Identification of hydrological trends in the presence of serial and cross correlations: A review of selected methods and their application to annual flow regimes of Canadian rivers. Journal of Hydrology 2009, 368, 117-130, doi:10.1016/j.jhydrol.2009.01.035.

52. Önöz, B.; Bayazit, M. Block bootstrap for Mann-Kendall trend test of serially dependent data. Hydrological Processes 2012, 26, 3552-3560, doi:10.1002/hyp.8438.

53. R Core Team. R: A Language and Environment for Statistical Computing. R Foundation for Statistical Computing. Vienna, Austria: 2019.

54. Pierce, D. ncdf4: Interface to Unidata netCDF (Version 4 or Earlier) Format Data Files. 2017. pp 36. Available online: https://cran.r-project.org/web/packages/ncdf4/ncdf4.pdf

55. Gudmundsson, L.S.; Stagge, J.H. SCI: Standardized Climate Indices such as SPI, SRI or SPEIR package version 1.0. 2016. pp 12. Available online: https://cran.rproject.org/web/packages/SCl/SCl.pdf

56. Zhong, R.; Chen, X.; Wang, Z.; Lai, C. scPDSI: Calculation of the Conventional and Self-Calibrating Palmer Drought Severity Index. 2018. pp 7. Available online: https://cran.rproject.org/web/packages/scPDSI/scPDSI.pdf 
57. Patakamuri, S. K.; O'Brien, N. Modified Versions of Mann Kendall and Spearman's Rho Trend Tests. 2019. pp 18. Available online: https://cran.rproject.org/web/packages/modifiedmk/modifiedmk.pdf

58. Rosell, S.; Holmer, B. RAINFALL CHANGE AND ITS IMPLICATIONS FOR BELG HARVEST IN SOUTH WOLLO, ETHIOPIA. Geografiska Annaler: Series A, Physical Geography 2007, 89, 287-299, doi:10.1111/j.1468-0459.2007.00327.x.

59. Byrne, M.P.; Pendergrass, A.G.; Rapp, A.D.; Wodzicki, K.R. Response of the Intertropical Convergence Zone to Climate Change: Location, Width, and Strength. Current Climate Change Reports 2018, 4, 355-370, doi:10.1007/s40641-018-0110-5. 